Tanker i bibliotekets have

Fik jeg nogensinde sagt farvel?

Krøb jeg, kaldende, på mine knæ,

gennem vejens våde græs til verdens ende

for endnu en gang at nå dig?

Lånte jeg en lærkes vinger

til at stige op i himlen

for at røre ved din pande,

hvor du sad, forløst, hos Gud?

Skrev jeg med mit hjerteblod dit navn uudsletteligt, mens jeg forblødte, eller gled du lydløst ind i mørket, uden jeg fik hvisket dig farvel?

Grethe Heltberg 


\section{Luftfotografiet i Det kongelige Biblioteks samlinger}

af overassistent Arne S. Andersen

Det kongelige Biblioteks erhvervelse af Sylvest Jensens store luftfotoarkiv i slutningen af 1990 foregik under betydelig opmærksomhed og vil således være mange bekendt. Mindre kendt er nok bibliotekets øvrige luftfotosamlinger, erhvervet gennem årene, som på væsentlige områder supplerer Sylvest Jensen.

Her en kort præsentation:

Nordisk Luftfoto (1928 - 33) ca. 2.000 optagelser.

Dansk Lufttaxa og Aero senere sammensluttet under navnet Aero Express (1931 - 47) ca. 5000 optagelser.

Nowico $(1933$ - 67) ca. 10.000 optagelser.

De store firmaer:

Sylvest Jensen (1936 - 87) ca. 11/2 mill. optagelser.

Ålborg Luftfoto ( 1938 - 67) ca. 300.000 optagelser.

Odense Luftfoto (ca. 1950 - slutn. af 60'erne) ca. 250.000 optagelser.

Endvidere må vi for fuldstændighedens skyld nævne Geodætisk Instituts optagelser fra perioden 1922 - 39. De tyske optagelser under krigen og Flyvertaktisk Kommandos optagelser (1985-88). De to sidste samlinger er endnu ikke tilgængelige. Sidstnævnte optagelser er fortrinsvis taget med kortlægningsformål for øje eller af militære hensyn. Der er tale om lodfotos taget fra stor højde (900-2400 m.)

De enkelte samlinger

Nordisk luftfoto (fotograf Eskild Fut Jensen) var et københavnerfirma. Motiverne er dels hentet fra København, dels fra provinsbyerne (som f.eks. bypar- 


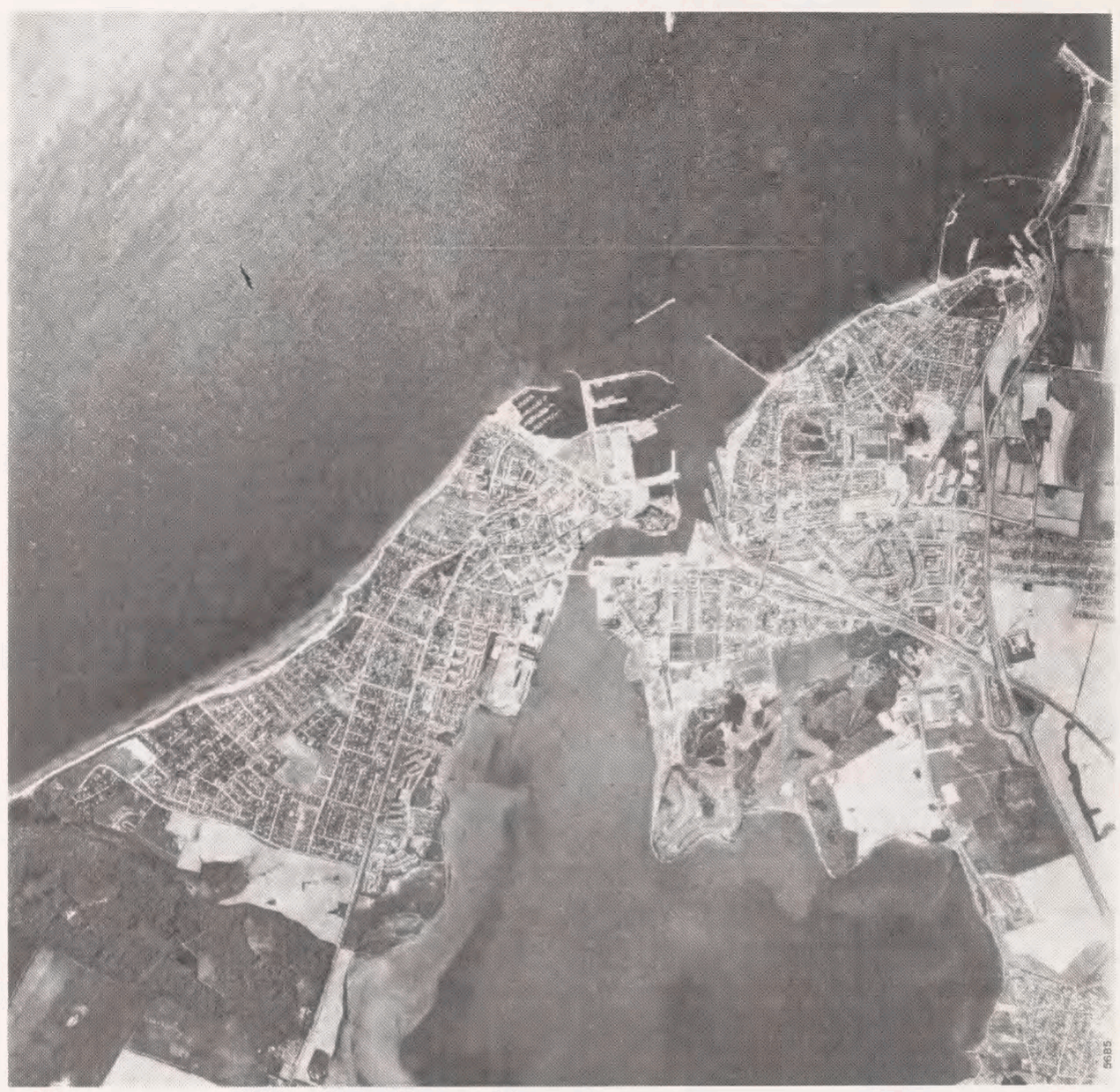

Luftfoto. Korsør. Flyvertaktisk Kommando. 1988.

tier og offentlige bygninger). Der er også en herregårdsserie, og som sådan peges der frem mod de senere store firmaer. Der er ingen registrant til Nordisk Luftfoto - indgangen er geografisk - på den pågældende by/herregård. Inden for sit begrænsede antal optagelser er der tale om spændende billeder og de er tidlige.

I lighed med Nordisk Luftfoto tager Aero Express og Nowico deres udgangspunkt i København, men optagelserne her går langt videre, dels i mængde og tid, dels i motiv. Her starter virksomhedsfotograferingen - i annoncer og på anden måde henvender man sig direkte til denne målgruppe.

Begge firmaer er meget væsentlige, når vi skal have et billede af den danske provinsby i 30`erne - i form af panoramaer, bypartier, gader og torve, 


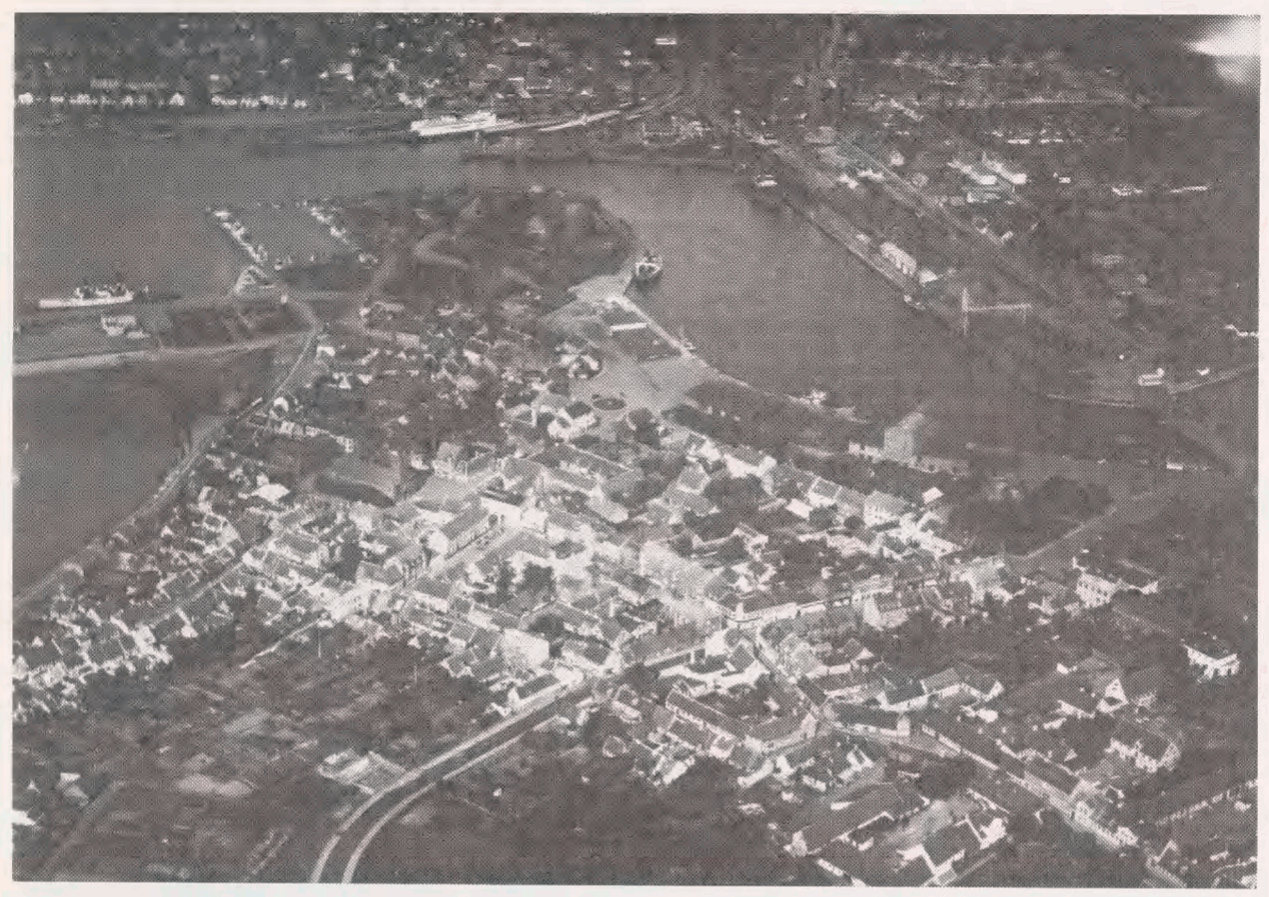

Skråfoto. Korsør. Aero Express. 1935.

de offentlige bygninger, virksomhederne. Firmaerne er meget nemme at arbejde med. Indgangen er alfabetisk på kartotekskort - på by/virksomhed / gade/institution. Som yderligere støtte er der for Nowicos vedkommende udarbejdet et vægkort, der dækker bypartier inden for Københavns kommune. Forespørgsler vedrørende København tager altid sit udgangspunkt inden for disse 2 firmaer. Begge firmaers billeder er relativt lette at datere og da især for Nowicos vedkommende, hvor optagelsesdato/år er noteret på negativet.

Da Viggo Sylvest Jensen i 1936 starter sit firma, sad Nowico og Aero Express tungt på København. Mulighederne var her begrænsede, og det skulle vare 20 år, før han tog kampen op. Der måtte være andre muligheder. Måske har han skelet til Nordisk Luftfotos herregårdsserie, i hvert fald får han øje på et helt nyt objekt: fotograferingen af den danske bondegård.

I tiden 1936-47 var Sylvest stort set eneherskende i Danmark, når det drejer sig om bondegårdsfotografering. Med udgangspunkt i sit domicil i Hillerød tog han naturligt nok sit udgangspunkt øst for Storebælt. I 1938-39 når han Fyn og den sydvestlige del af Jylland. Krigen sætter en stopper for den 


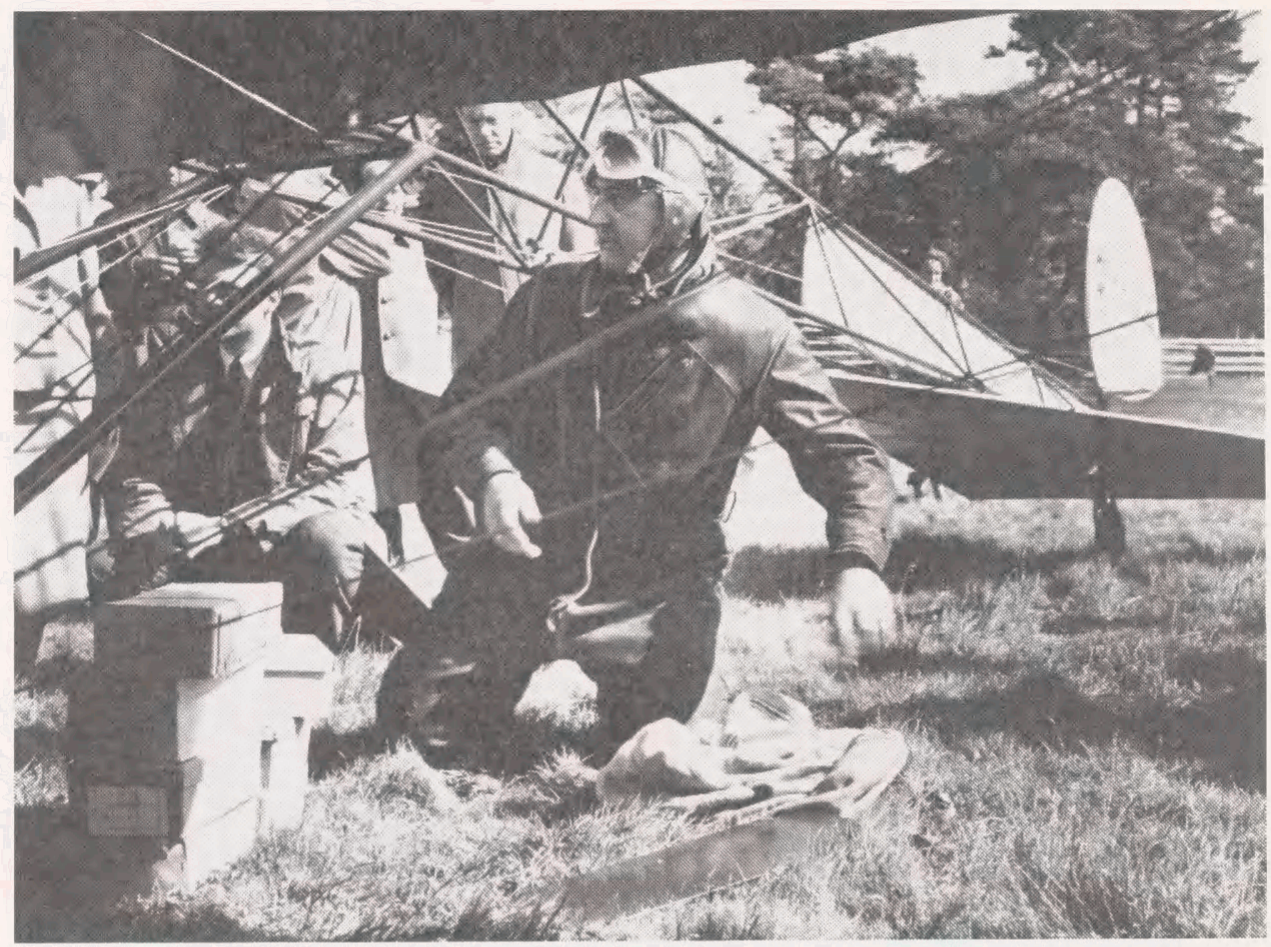

Viggo Sylvest Jensen. 1956.

videre fotografering. Først i 1946 kan han fortsætte sit arbejde. Turen kommer nu til resten af Jylland, og i 1950 er hele landet dækket.

Apparatet er et småbilledkamera 24×36 mm.-Leica. Optagelsen foregår relativt tæt på objektet - bondegården - kameravinkel ca. $50^{\circ}$. Det færdige billede viser nu gården-med gårdsplads samt haven-og ikke meget mere. Det er det vi kan kalde den klassiske fotografering af den danske bondegård. Kvaliteten er i almindelighed fremragende.

Gårdfotograferingen var og blev grundlaget i Sylvests virksomhed, men når han nu alligevel var i området, var det også naturligt at inddrage andre interessante objekter: provinsbyen, landsbyen som panorama - også noget nyt - og herregårdene. Det jeg vil kalde "den klassiske herregårdsserie" går fra 1936-39 og dækker samme område som Leica-serien.

Til disse fotograferinger med et noget større objekt benytter Sylvest et Nettel camera med et 9x12 negativformat - efter krigen afløst af Kodak med $13 \times 14$ negativer. Fotograferingsmåden er principielt den samme som for Leicaoptagelserne, dog befinder maskinen sig, naturligt nok, højere oppe. 
Indgangen til denne serie-Nettel/Kodak-serien (12.000 opt.) er alfabetisk/geografisk i protokolform. Man slår blot op på den pågældende herregård/by. For deenkeltebyoptagelsers vedkommendeer der objektbeskrivelse: deter helebyen, kvarteretomkring Store Torv, havnen, gasværket, jernstøberiet etc. Fremragende kvalitet - en meget væsentlig serie.

Når Sylvest i 1950 har været hele landet rundt, betyder det ikke, at samtlige ejendomme er fotograferet. Der er en tendens til, at han i første fotograferingsrunde vælger de lidt større gårde, antagelig med henblik på afsætningsmulighederne i firmaets opstartfase. Efter krigen samtidig med Jyllandsfotograferingen - og firmaets udvikling - påbegynder han en mere grundig fotografering af allerede kendte områder. Ofte med en allerede fotograferet ejendom som objekt blot fra en anden vinkel, men mange nye kommer til. Og det viste sig jo også,at selv de mindre brug ønskede billeder.

\section{H-serien}

I slutningen af 40’erne begynder Sylvest Jensen at møde konkurrence fra andre luftfotofirmaer, samtidig med at markedet til en vis grad måtte siges at være mættet med den gængse form for fotografier. Det er med dette som baggrund, atSylvesti 1950 introducerer en ny type billeder: Horisontoptagelsen.

Ved denne form for fotografering er maskinen længere nede og kameravinklen betydelig mindre, omkring de $25^{\circ}$. Dette bevirker, at vi på det færdige billedehargården i forgrunden, debagved liggendemarker m. naboejendomme og til sidst horisont og himmel. Der var i realiteten tale om et nyt produkt.

For kunden betød det, at han fik et billede af sin ejendom, ikke alene bygningerne men også markerne. Og så var det pænt. Denne type billeder egner sig i billedmæssig henseende bedre til colorering end de traditionelle optagelser. Forrest har vi gården med rødstens stuehus og hvide længer med stråtag, i baggrunden gule og grønne marker med lidt skov og længst ude blå himmel med hvide skyer. Det var næsten som et maleri og pænt at have hængende i "den fine stue".

Vi regner med, at Sylvests Leica-serie omfatter omkring 220.000 optagelser. H-serien, som blev dens afløser, kommer op på omkring de 600.000, og er som sådan Sylvests største serie. Apparatet, der blev brugt til disseoptagelser i $\mathrm{H}$-serien var et Hasselblad camera med negativer i format $14 \times 14 \mathrm{~cm}$. 


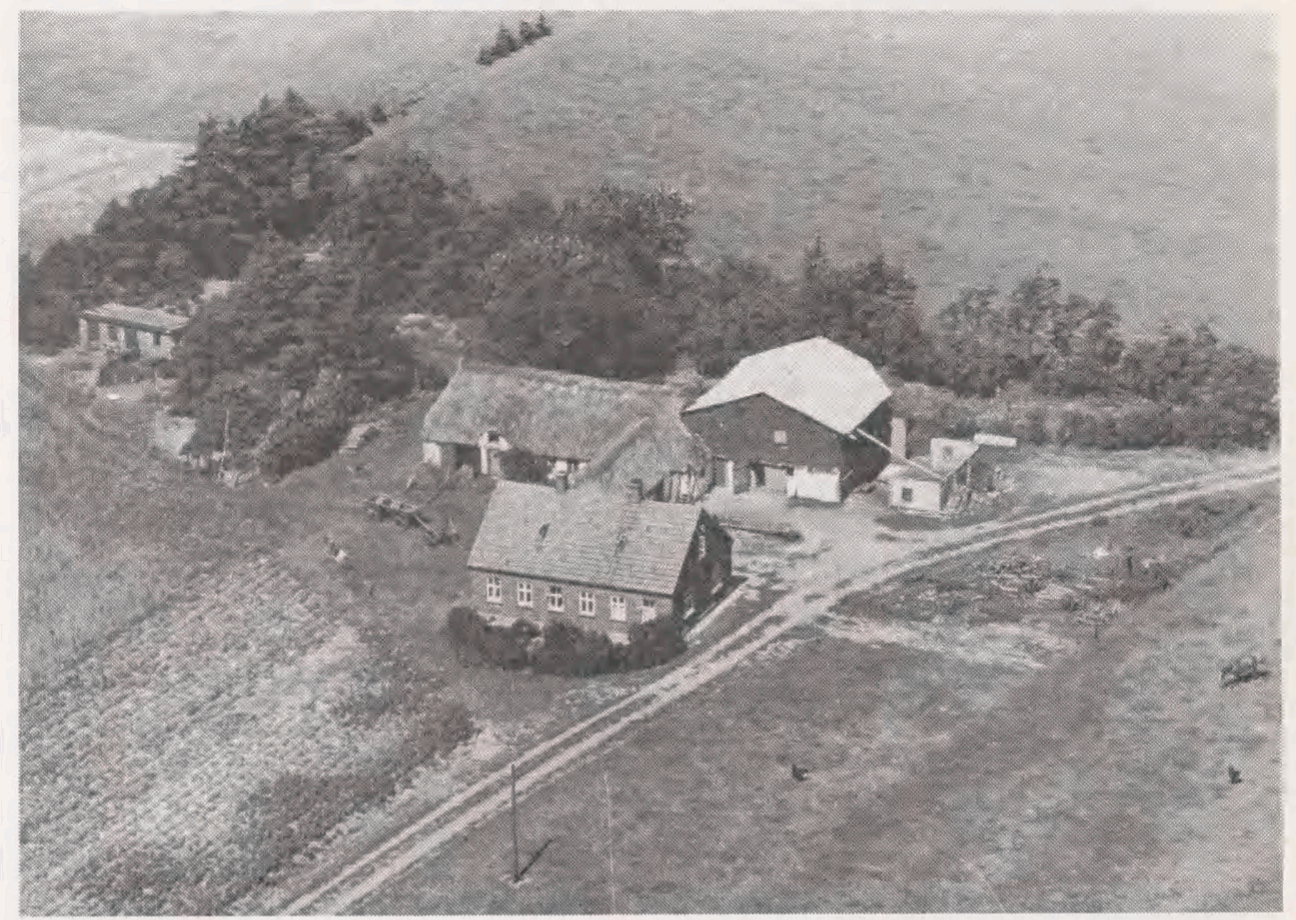

Traditionel optagelse. Ejendom ved Ho pr. Oksbøl. 1948.

H-optagelserne giver som sagt et æstetisk smukt billede - og en placering af gården i landskabet. For den, der imidlertid i højere grad er interesseret i selve gården, bygninger, detaljer, er Leica-optagelserneat foretrække, her får man t.eks. gårdspladsen med.

H-seriens sort/hvide optagelser fortsætter frem til 1979, men horisontoptagelserne slutter i 1974. Horisontoptagelser forudsætter lav flyvehøjde, og somme tider blev det for lavt - der skete ulykker. Dette foranlediger Luftfartsdirektoratet til i 1974 at fastsætte regler m.h.t. flyvehøjde ved luftfotografering. Det betyder, at man i dette år vender tilbage til den traditionelle fotograferingsform.

Først i 1979 påbegynder firmaet Sylvest Jensen gårdfotografering i farver, på et tidspunkt hvor andre firmaer forlængst havde påbegyndt dette. Denne sidste serie af gårdoptagelser, V-serien (V=vericolor) omfatter ca. 35.000 optagelser og dækker perioden 1979-83. På dette tidspunkt er firmaet kun en svag afglans af tidligere tider. Optagelserne ligger spredt ud over landet med et tyngdepunkt i Jylland. Man udvælger sig områder, hvor der er forventning om et rimeligt salg. De sene $\mathrm{H}$-optagelser og V-serien illustrerer 


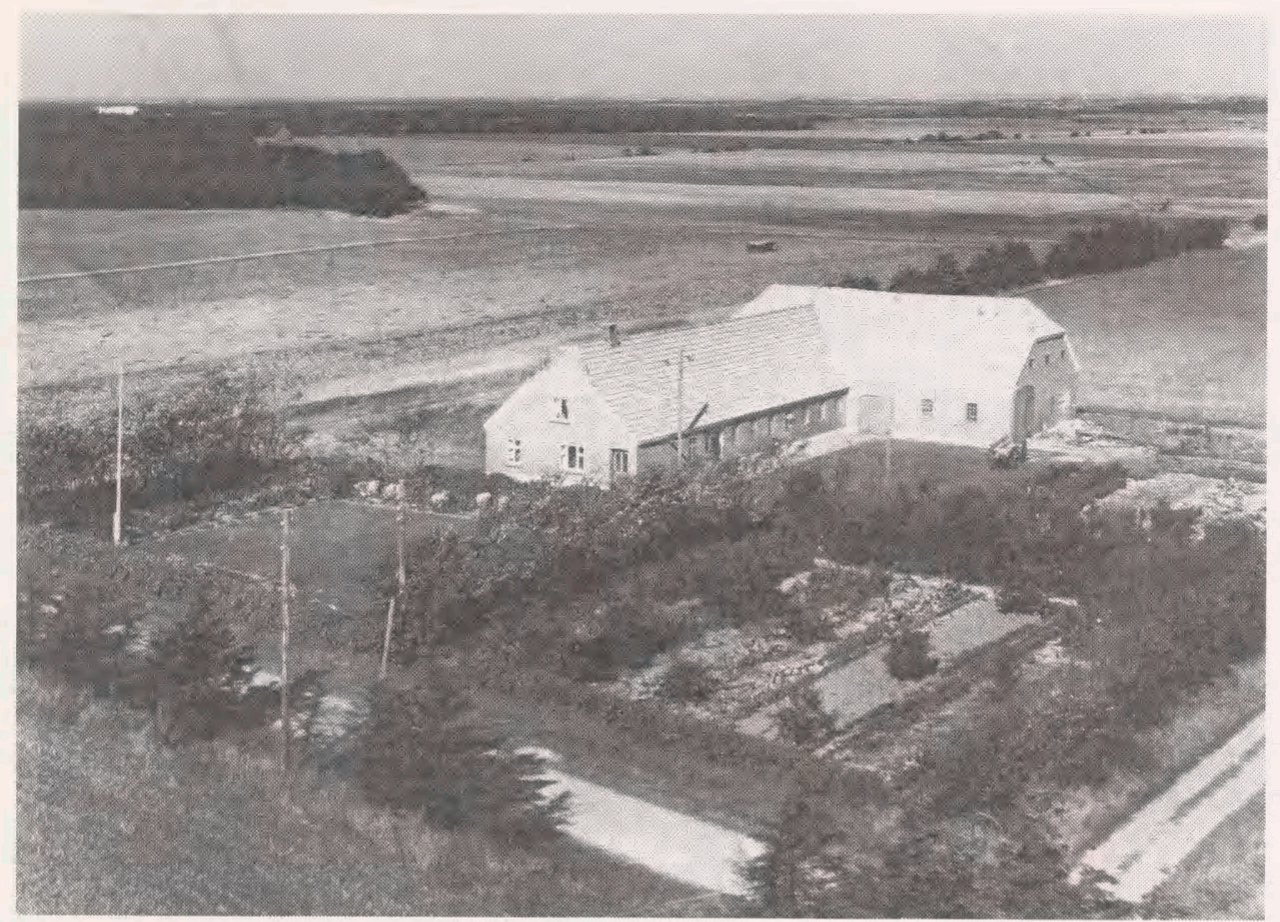

Horisontoptagelse. Ejendom ved Hammel. 1956.

den voldsomme forandring, der sker med den danske bondegård i 70`erne og 80 'erne. Hvis man vil tegne et billede af den danske bondegårds bebyggelsesmæssige udvikling, er det med disse billeder, man starter - og derefter gås tilbage $\mathrm{i}$ tiden.

Slutningen af 40'erne og hele 50'erne er luftfotograferingens store periode. År efter år flyver Sylvests maskiner landet tyndt, område efter område bliver fotograferet, den samme gård ofte flere gange, forfra og skråt fra siden. Og for kunderne var det jo interessant, at eks. den nye svinestald var med på billedet.

Året 1956 danner et nyt skel i firmaet Sylvest Jensens udvikling. Det er det helt karakteristiske for Sylvest Jensen i forhold til andre firmaer, som koncentreredesig om gårdfotografering, at han er altomfattende. Det er detår, han for alvor går i gang med byoptagelserne. Vi har tidligere haft byoptagelser i Nettel-Kodak-serien, også i Leica findes de. Nu gås der systematisk til værks.

I 1956 fotograferes så at sige alle landets lidt større landsbyer i panoramaform, almindeligvis med 2-4 billeder. De var velegnede til væggen på skolen og især da som postkort til forhandling i den lokale brugs. Og 


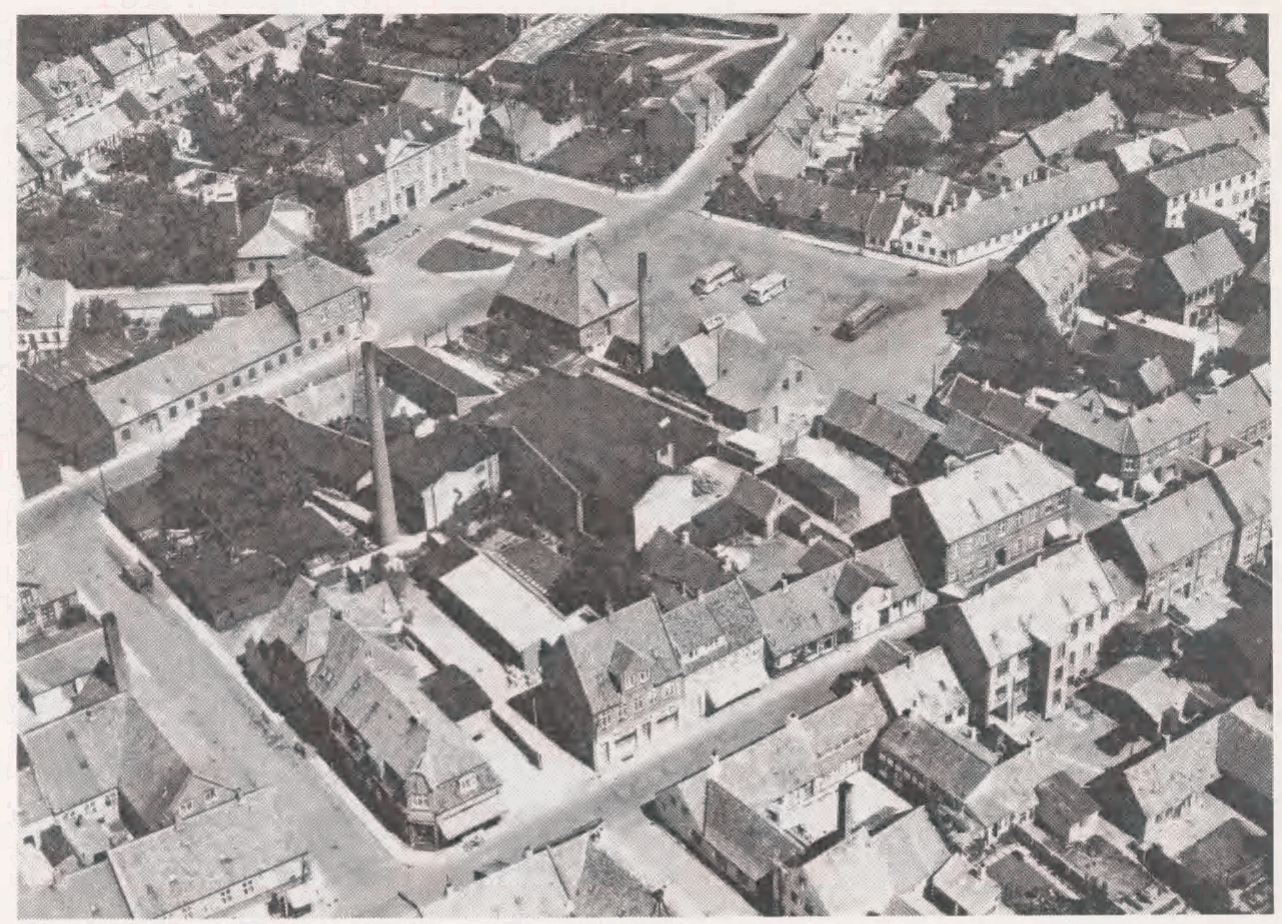

Grenå, torvet. 1956.

købstæderne - alle landets købstæder bliver fotograferet. Motiverneer dem, vi kender fra Nettel-Kodak: Panoramaer, bypartier, virksomheder, institutioner. Via de mange bypartioptagelser kan vi på det nærmeste sammenstykke et billede af, hvordan den danske provinsby så ud i 1956-på nært hold!

Fra 1958 supplerer Sylvest disse optagelser med fotografier af de enkelte ejendomme. For mange landsbyers vedkommende er hvert eneste hus fotograferet. Her var afsætningen rimelig. I provinsbyerne koncentrerede han sig om de opvoksende forstæder - et nyt kundegrundlag? Men her var successen begrænset. Det kan hænge sammen med, at byboer har mindre veneration for deres ejendom end landboer? Nok så væsentligt er dog at de fleste parcelhuse ganske enkelt ikke egner sig til at blive taget fra luften. Det var således i almindelighed ikke noget "smukt" produkt repræsentanten kunne forevise kunden, når han bankede på.

Mere held havde Sylvest ved virksomhedsfotograferingen, f.eks. tankstationer, og da især hos den nye industri, der grupperede sig om den gamle by. Her kommer bestillingsarbejdet ind. Man kunne ringe og bestille luftoptagelser af sin virksomhed, til ophængning og i forretningsøjemed. 
Denne form for fotografering får efterhånden større betydning for firmaet Sylvest Jensen.

Endelig er 1956 også året, hvor Sylvest går igang med København. Vi har hørt, at Aero Express og Nowico var dominerende her, men på dette tidspunkt er Aero Express ophørt, og Nowico har mistet pusten - Sylvest øjner chancen.

Der eksisterer rigtig mange byoptagelser af København fra 1956 og frem, motiverne er de kendte: torve og pladser, offentlige bygninger, gas- og elværker, seværdigheder etc. Og for den, der vil danne sig et billede af industrier og virksomheder i København i 50`erne og 60`erne, er Sylvest ikke til at komme uden om. Det gælder både Glostrup og Herlev som de mere centrale dele af København. En virksomhed som Carlsberg er f.eks. repræsenteret med op mod 100 optagelser taget gennem tiden. Billederne har Sylvest dels taget på eget initiativ dels som bestillingsarbejde.

Sylvests Københavns optagelser i B-serien ( $\mathrm{B}=$ byer) kan være vanskelig at bruge. F.eks. dækkes København af 10-15 hovednumre og hvert hovednummer rummer flere hundrede optagelser. Der må bladres mange protokolsider igennem, når man søger den enkelte virksomhed. Ofte vil foretagendet dog krones med held, men det er helt klart et område, hvor en mere overskuelig registrering er stærkt påkrævet.

I 1974 går fa. Sylvest over til at fotografere virksomhederne i farver, bestillingsarbejdet bliver nu dominerende. Indgangen er her kortbøger: Kraks kort over København samt Danmark 1:200.000. Og for diasseriens vedkommende: alfabetisk protokol. Her kommer andre motiver også ind. Sylvests virksomhedsfotografering fortsætter frem til firmaets ophør.

Hvorfor starter Sylvest den systematiske byfotografering i 1956? Svaret kan liggei, at han vurderer bondegårdsmarkedet som ved at være mættet - det kan ligge i nye udfordringer. Et andet svar kan ligge i den stærke konkurrence. Der var kommet andre luftfotofirmaer på banen tilskyndet af Sylvest Jensens succes. To af disse er Ålborg og Odense Luftfoto.

Ålborg Luftfoto kommer først. De starter i 1948. I begyndelsen med klassisk/traditionel fotograferingsform som Sylvests Leica-optagelser. Den såkaldte A-serie. Senere med horisontoptagelser: H-serien, ikke at forveksle med Sylvests ditto. Hvis man skal pege på forskellemellem Sylvest og Ålborg, kan én være, at Ålborg Luftfoto har en tendens til at fotografere mere ydmygt. 
Ganske vist har Sylvest mindre ejendomme og husmandssteder med, men Ålborg fotograferer mere grundigt. I et tilfælde har man fået taget et hønsehus! Hvad repræsentanten lakonisk meddeler hovedkontoret.

Af de to firmaer er det nok Odense Luftfoto, der har haft det sværest i konkurrencen med Sylvest. Ålborg Luftfoto starter tidligere og i et område, der kun er relativt tyndt dækket af Sylvest. Odenses område var dyrket mark. En mulighed var det, vi med et moderne ord kalder produktdifferentiering. Vi har set, at Ålborg har været inde på samme tankegang ved at tilbyde flere ejendomme end Sylvest. Odense vælger i deres horisontoptagelser at lade deres maskiner flyve meget lavt og med endnu mindre kameravinkel. Herved adskiller produktet sig lidt fra det, forgængeren har præsteret. Det kan der komme smukke billeder ud af, hvor baggrunden indicerer det, som vi eks. ser det i optagelser fra Vejle Ådal.

Alligevel har det været svært. Utallige er de notater, repræsentanten har påført bagsiden af prøvebilledet, som lyder i retning af: "Ejeren har flere billeder, nu er det slut". Eller: "I dette område har alle colorerede billeder af SJ. Intet salg."

Odense og Ålborg Luftfoto arbejder alenei det åbne land og i landsbyen. Byerne forblev Sylvests domæne. Der er dateringsproblemer, når det drejer sig om Odense og Ålborgs optagelser. Sværest er det for Ålborgs tidlige Aserie, for de senere optagelsers vedkommende er der lejlighedsvis datering på bagsiden. Men der forestår et stykke arbejde.

\section{Dækningsgrad}

I den mængde af luftfotooptagelser, Det kongelige Bibliotek er i besiddelse af og i bevidstheden om, at mange ejendomme er taget op til 4-5 gange alene i Sylvest, er det naturligt at spørge om samtlige landets fritliggende ejendomme er fotograferet?

Svaret er nej! I hvert fald rummes de ikke i vore samlinger.

Geografisk set er helelandet dækket. Dog således at nogle egne af landet er mindre hyppigt fotograferet end andre. Således har Sylvest fin dækning i Bornholm frem til 1969, derefter rettes blikket mod andre egne. Horns herred er generelt svagt repræsenteret på trods af den nære beliggenhed til Hillerød. Værst ser situationen dog ud for den centrale og vestlige del af Sønderjylland. 


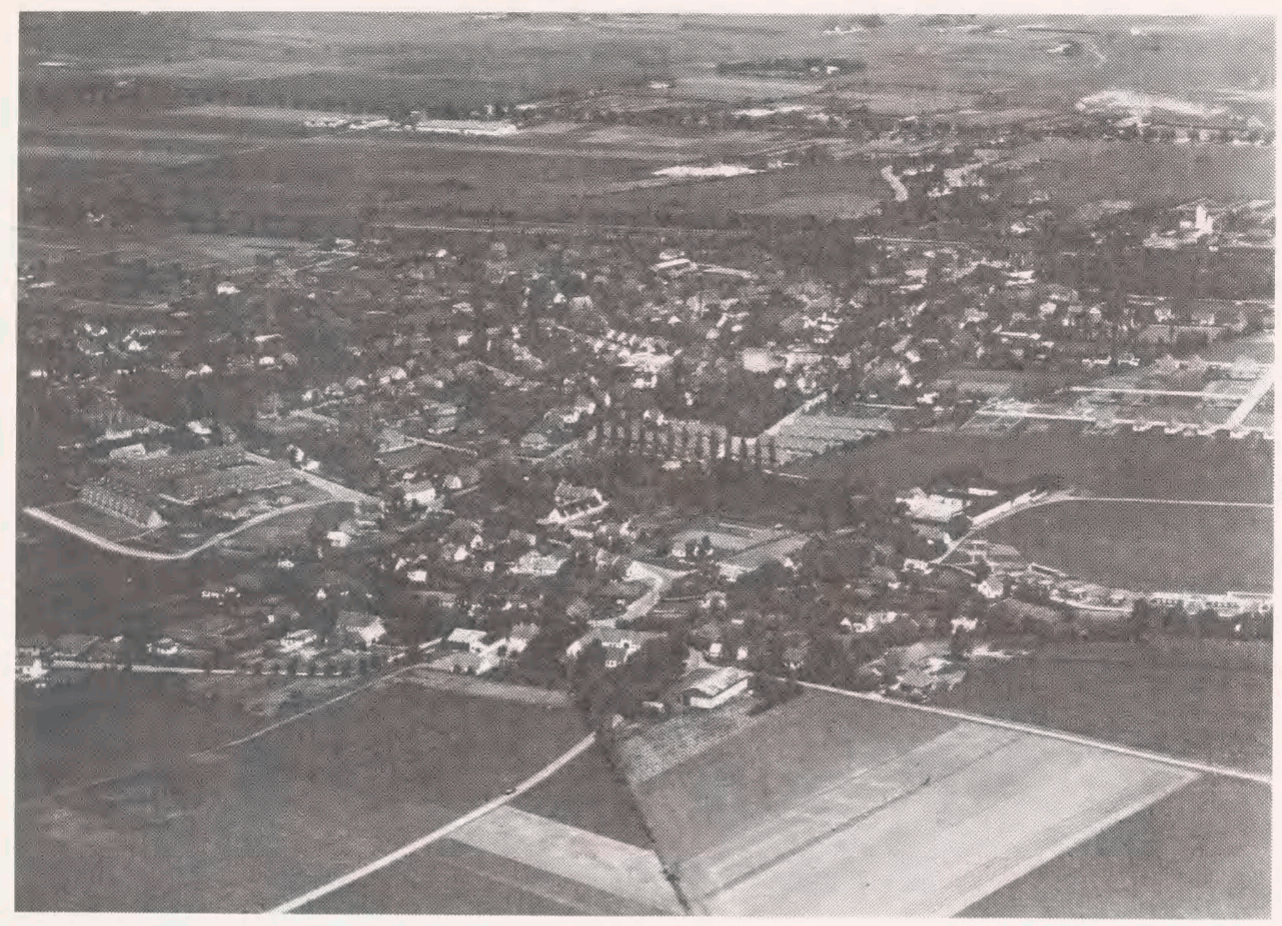

Tåstrup by. Ca. 1949.

Dette kan skyldes tilstedeværelsen af andre luftfotofirmaer som f.eks. Sønderborg Luftfoto.

Firmaerne konkurrerede på livet løs, men samtidig er der også en tendens til opdeling. Ålborg Luftfoto koncentrerede sig næsten udelukkende om Jylland. Odense Luftfoto tog sig af Fyn, dele af Jylland, samt Vestsjælland. Sylvest blev - som bekendt - landsdækkende.

Luftfotografering var en forretning, billederne skulle sælges. Derfor er hovedmotivet den enkelte ejendom med ejeren og hans familie som kundegrundlag. For landsbyens vedkommende har vi som sikre objekter: smeden, brugsen, kirken og præstegården, møllen, mejeriet og skolen. Og mange fattiggårde. Som for købstadens vedkommende kan vi sammenstykke et billede af landsbyen i 50'erne - endnu tættere end for byen. Ofte bliver vi spurgt om lossepladser og grusgrave. Svaret er almindeligvis et nej. Her var der ikke umiddelbart en salgsmulighed. Hvor der er tale om egentlig fabrikation som eks. i brunkulslejerne er chancen større. Her kunne der sælges til driftsleder og arbejdere. 


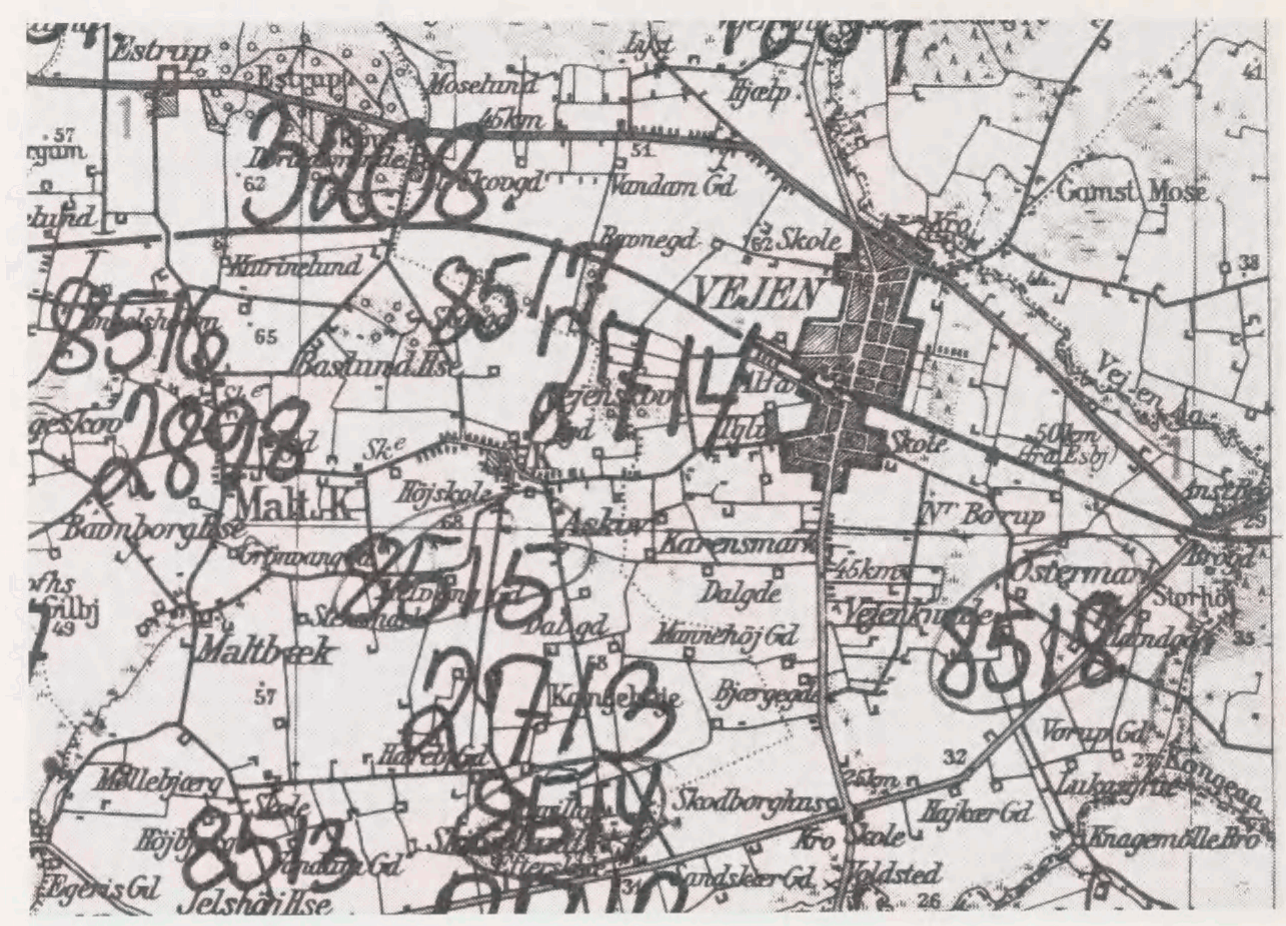

Sylvest Jensen kortblad.

\section{Efter fotograferingen}

Flyvesæsonen starter i begyndelsen af maj og slutter omkring 1. oktober. Sæsonen er naturligvis bestemt af, at det er på dette tidspunkt, det er godt flyvevejr og mulighed for skarpe optagelser, men også af, at kunderne ønskede sommerbilleder.

Det er om sommeren, bondegården tager sig fordelagtigst ud. Efter fotograferingen er det repræsentantens tur. Udstyret med et prøvebillede af ejendommen ankommer repræsentanten til gården i sin Morris for at afsætte sin vare. Ofteer der gevinst. Vi kan af protokollerne se, at salget især i perioden op til midten af 50'erne har været kolossalt. Evt. afsluttes der en handel omkring et coloreret billede. Kunde og repræsentant bliver nu enige om hvilke farver gård og omgivelser skal have, og det ned til de mindste detaljer. Der kan være behov for nogle korrektioner. Evt. har vasketøjet hængt ude, det skal retoucheres bort. Det kan være sommerblomsterne i haven endnu ikke er kommet op, så må de med. Det kan være, at møddingen er kommet med på 


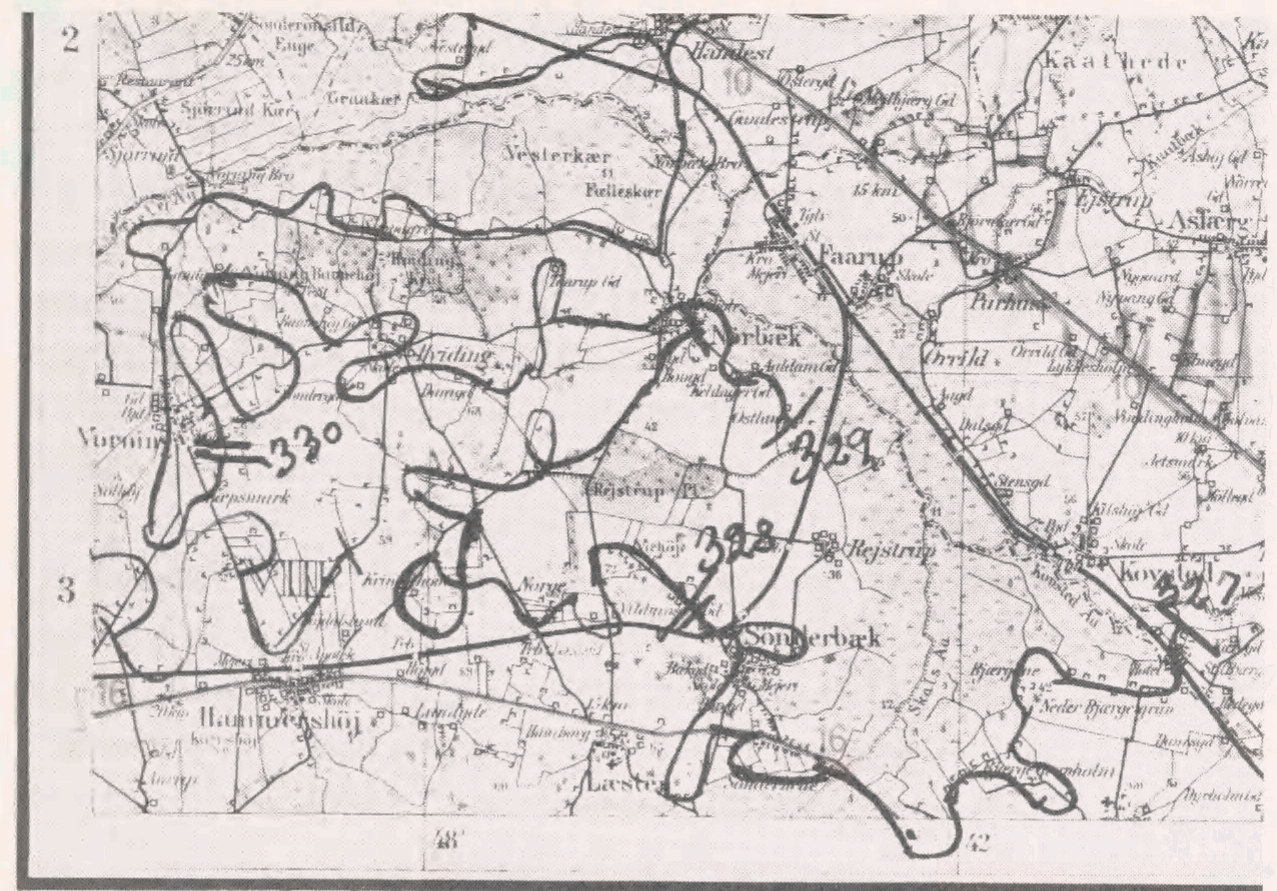

Ålborg Luftfoto kortblad.

billedet, og kunden ikke ønsker dette. Farvebeskrivelse og evt. korrektioner påføres prøvebilledet, som derefter går til firmaets atelier og colorist til videre foranstaltning.

Hermed er repræsentantens arbejde slut,og han kan fortsætte til næste gård. Efter mange kopper kaffe kan dagen så afsluttes på købstadshotellet (Harmonien?),hvor han kan planlægge næste dags besøgsrute.

På bagsiden af mange af Odense Luftfotos prøvebilleder er der påført oplysninger - i de tilfælde, hvor der ikke er sket salg.

Disse oplysninger tjener dels som bevis over for hovedkontoret, at repræsentanten vitterlig har besøgt ejendommen, dels som en vejledning for senere sælgere m.h.t. salgsmuligheder. Ofte går oplysningen på, at kunden har billeder i forvejen og ikke ønsker flere. Andre gange vurderes kundens økonomiske formåen: "Meget gamle folk", eller "manden har været syg, har ikke råd", og om modtagelsen: "Konen meget sur". Mere positivt: "Manden vil gerne have et billede, når den nye lade er færdig". Her er et emne for næste fotograferingsrunde. 
Uanset om det er Sylvest, Odense eller Ålborg Luftfoto, er der 2 forudsætninger, der skal være til stede, for at en søgning kan lykkes. Ejendommens nøjagtige beliggenhed (f.eks. i forhold til nærmeste landsby) samt ejerens navn $i$ den periode, man er interesseret $i$ at få billeder fra. Oplysning om evt. gårdnavn er en yderligere støtte, men ingen betingelse. Lad os tage et eksempel. Kunden ønsker et billede af en ejendom (gård) beliggende ca. $3 \mathrm{~km}$. vest for Vejen by, midten af 50'erne, daværende ejer er Svend Nielsen. Hovedindgangen er topografisk i form af vægkort eller kortblade.

Hvert tal markerer en film med ca. 36 optagelser (ejendomme). For Sylvests vedkommende markerer cirklen det område, der er fotograferet. (Indgangen til Odense Luftfoto er principielt den samme). Ålborg Luftfoto har valgt at angive optagelsesmønstret ved markering af flyveruten (med filmsnr.). En søgning starter altid i Sylvest. Sylvest Jensen har protokoller, der angiver den enkelte optagelse med evt. gårdnavn, ejernavn og beliggenhed. Odense og Ålborg førte ikke protokoller over optagelserne, oplysninger om ejernavn / beliggenhed findes bag på prøvebillederne, som man altså må bladre igennem.

Vi vælger at gå ind på Sylvest Jensen protokollen dækkende nummeret H 8517 (se modstående side):

Her er ingen Svend Nielsen. Vi tager derefter det tilgrænsende nummer H 8516 og ser, at optagelse nr. 35 dækker en optagelse med det pågældende ejernavn. Herefter er det blot en opringning til kunden for at få bekræftet gårdens udseende. For at få flere billeder kan søgningen udstrækkes til Ålborg/Odense eller til tidligere/senere optagelser af Sylvest. Nøjagtig beliggenhed/daværende ejer er alfa og omega. En forespørgsel fra nuværende ejer Peter Jensen, Haderslevvej 142, Vejen, om et billede af samme ejendom matr.nr. 4622 er således umulig at have at gøre med, hvis ovennævnte oplysninger ikke er til stede.

Dette var et eksempel på en H-protokol. I de tilfælde, hvor kunden kun kan oplyse gårdens navn/beliggenhed, må vi gå til Sylvests tidlige optagelser i Leicaprotokollerne. Det er slående, hvor omhyggeligt disse er ført. Gårdens beliggenhed er anført med største præcision, og hvor et gårdnavn overhovedet har været til at opdrive, er dette med. Senere op i tiden bliver oplysnin- 


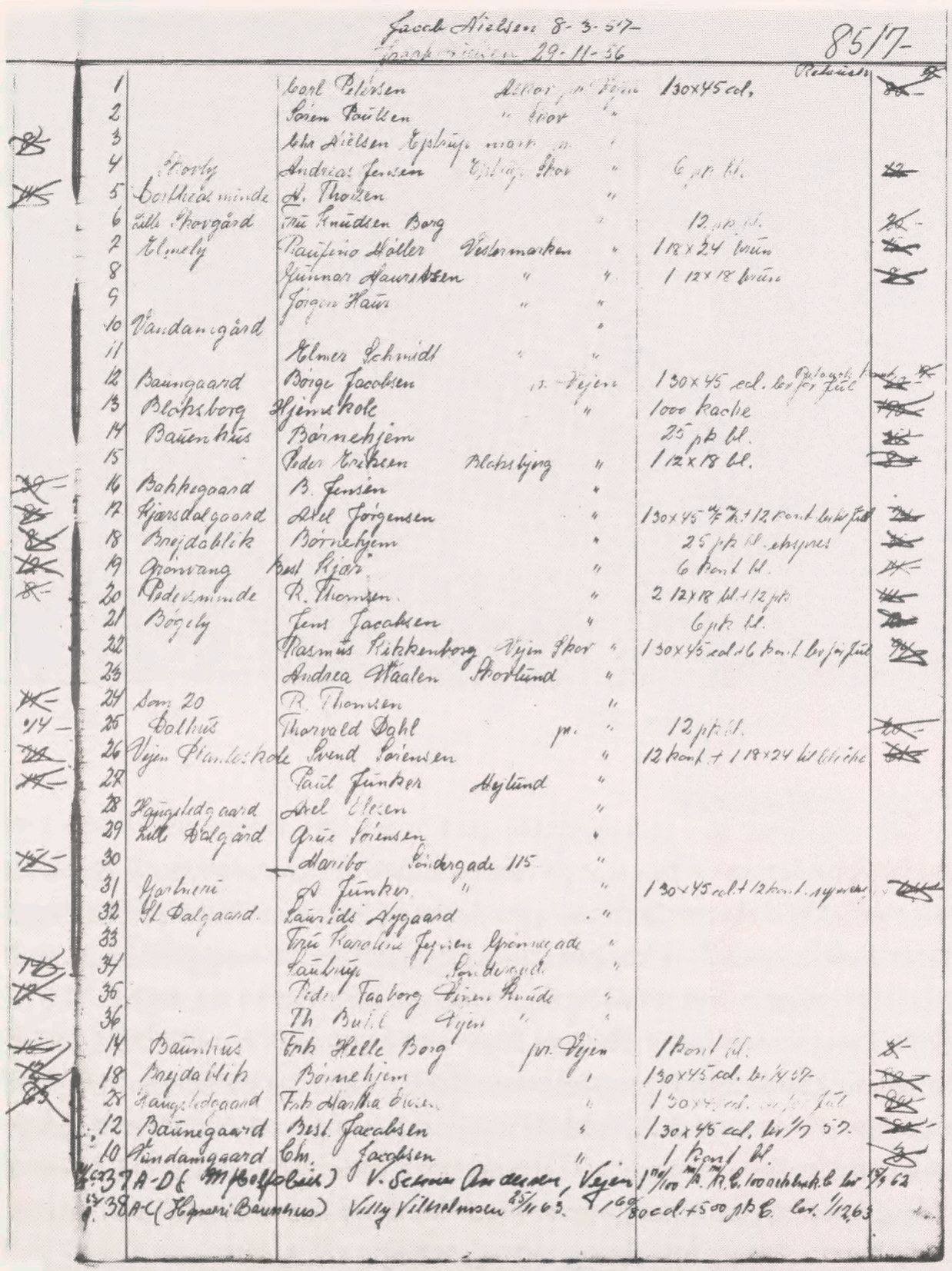

gerne mere mangelfulde. Først er det gårdnavnene, der forsvinder, og i slutningen af Sylvest Jensens periode anføres ofte kun ejernavn, forsåvidt salg har fundet sted. 


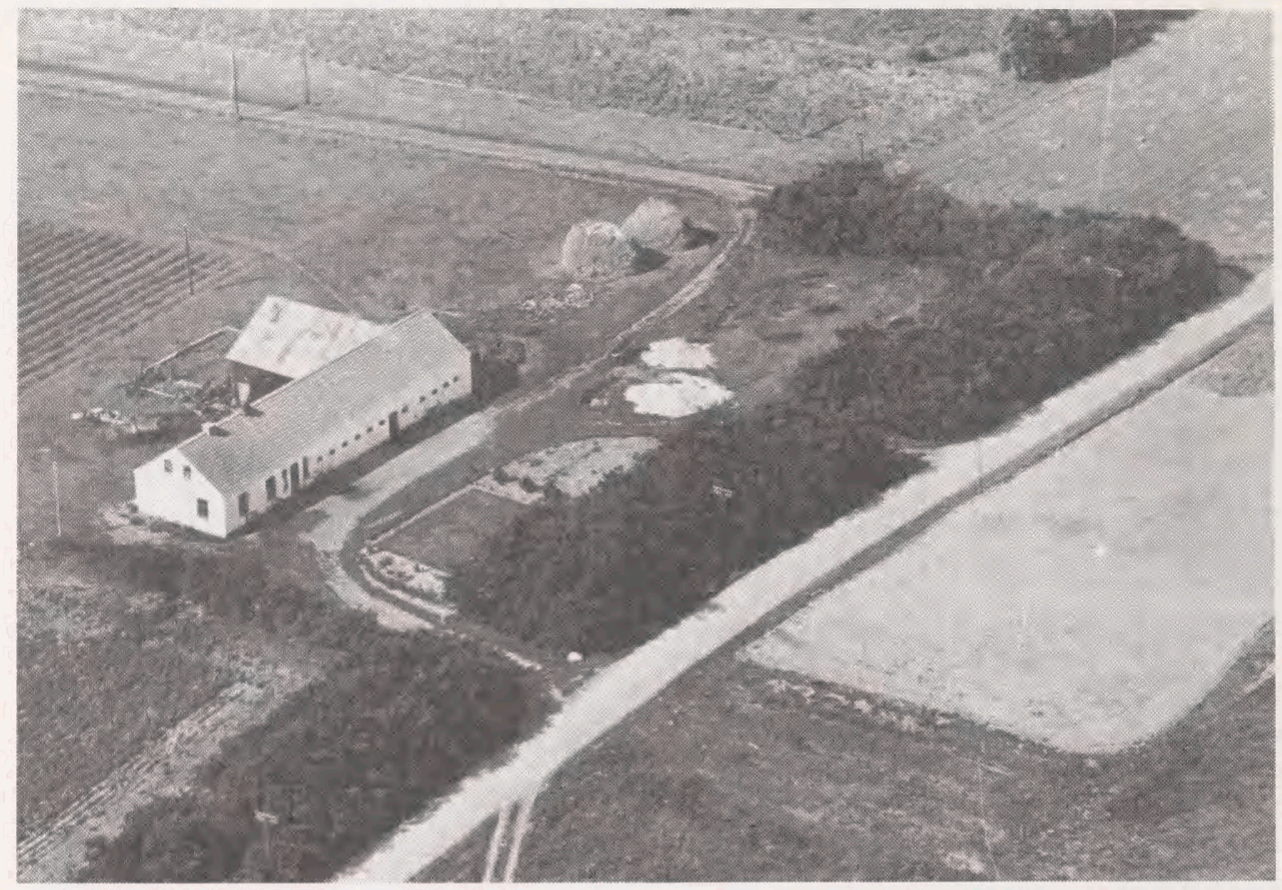

Vidumgård på Herningegnen. 1948.

\section{Brugen af billederne}

Umiddelbart kommer der mange henvendelser fra personer, som gerne vil have et billede af slægtsgården - og gerne det ældste. Men billederne kan også bruges tilat illustrere udviklingen i landbrugssamfundet, bebyggelseshistorisk og kulturhistorisk. For landsbyens vedkommende har vi set, vi kan låse et billede fast af landsbyen i 50’erne. Hvad der er umiddelbart slående ved at betragte de gamle bondegårdsbilleder er den ro, der er i billederne - bygningerne står i et harmonisk forhold til hinanden. Denne harmoni bliver sprængt gennem tiden. Ikke så meget ved at stråtaget afløses ved det faste tag. I højere grad ved at den gamle længe giver plads for den nye svinestald - ved de nye tilbygninger - ved gylletanke og tørringsanlæg.

Ud fra en byplansmæssig tankegang er det interessant at have billeder fra provinsbyen i 50’erne, gadeforløb, enkeltejendomme - billeder som ofte kan suppleres med tidligere og senere optagelser. Luftfotoet har værdi ved ved restaureringsopgaver, posthuse og jernbanestationer blot som eks. De lokalhistoriske arkiver er dybt interesserede, men her spiller økonomiske 


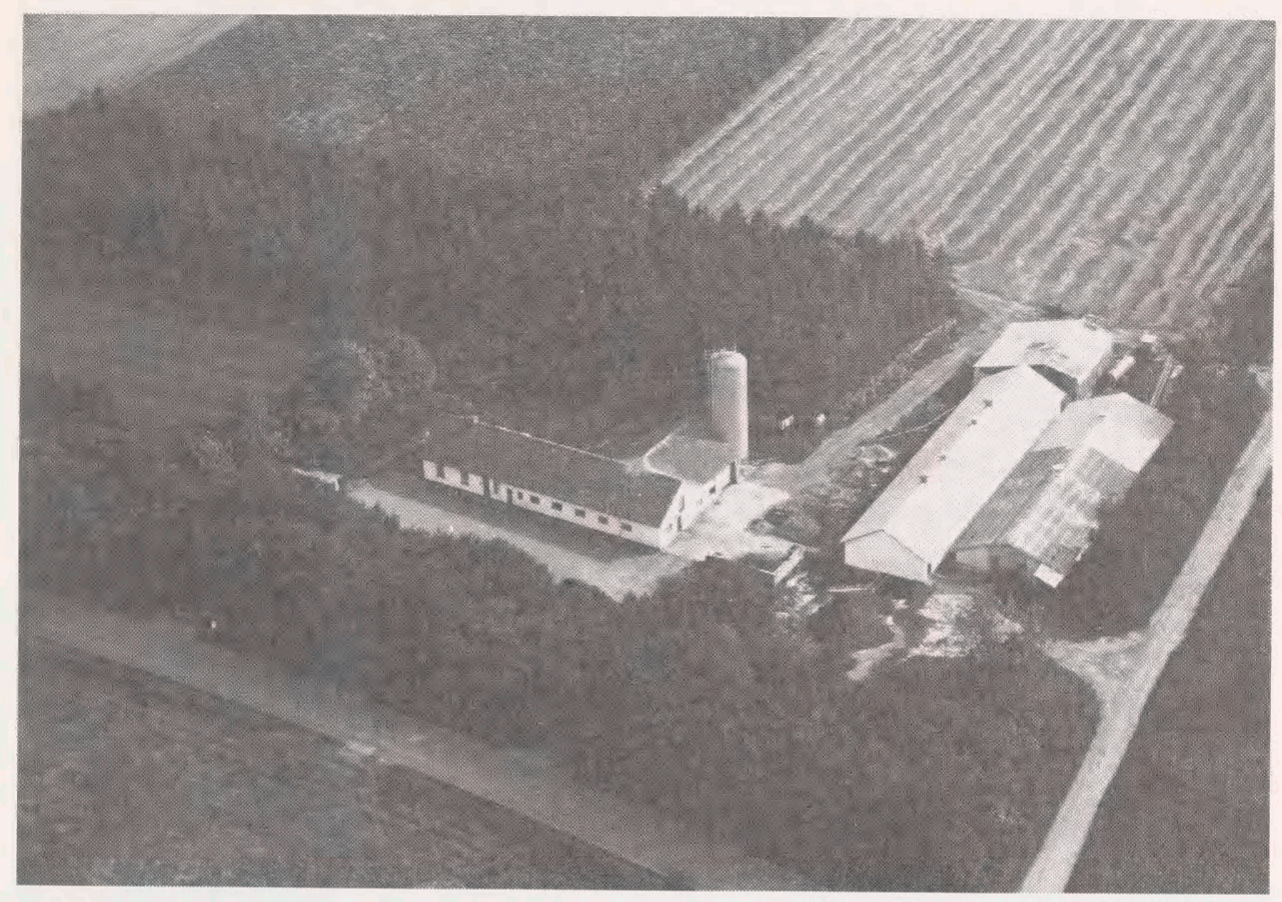

Vidumgård. 1979.

overvejelser en alt for stor rolle. I de sidste par år har luftfotoet fået en miljømæssig betydning i forbindelse med den igangværende industrikortlægning af Danmark. De mange, mange virksomhedsoptagelser er her interessante - til bestemmelse af beliggenhed, tromleoplag, affaldsdepoter etc. $\mathrm{Og}$ de sene optagelser i B-serien, som først og fremmest viser villaer, og som vi synes er grimme - hvad kunderne også syntes - får i den henseende ny betydning. For sammen med parcelhusene fotograferede man eksempelvis også tankstationer, renserier og autoværksteder. I 50’erne havde nær sagt hver en købmand og brugs i småbyerne eget benzinsalg. Her har vi billederne. Og det er vigtigt, vi kan hjælpe. Stikprøver har således påvist forurening på 80 $\%$ af de grunde, hvorfra der tidligere har foregået salg af benzin.

Slutning

Tiden op til omkring 1960 er luftfotografiets store periode. Nu begynder vinden at blæse den anden vej. Markedet er ved at være mættet. Man prøver 


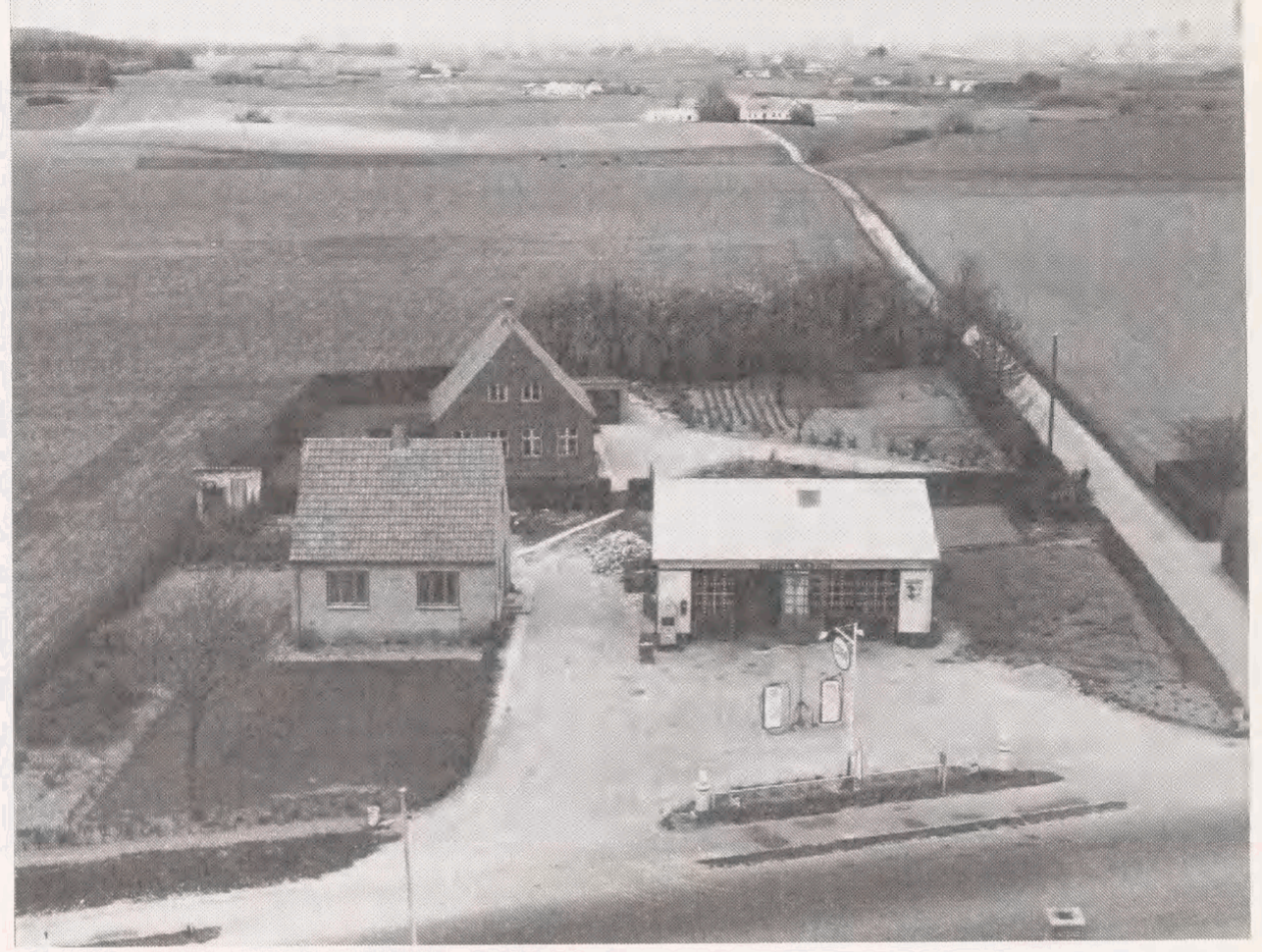

Benzinsalg. Torkilstrup, Sjælland. 1956.

at finde nye kunder. Villafotograferingen er her et eksempel - men successen var begrænset. Endnu værre gik det, da Sylvest i en periode forsøgte sig med parcelhusfotografering på jordplan, villaen fotograferet forfra fra vejen - så langt fra luftfoto som tænkes kan. Af endnu større betydning har været den befolkningsmæssige udvikling på landet. Nedgangen i antallet af selvstændige landbrug er allerede startet i 50’erne, men tager rigtig fart i 60'erne og 70’erne. Kundegrundlaget svinder. Man forsøger sig med nye produkter. Et billede af bondegården kan nu også købes i form af platter til ophæng på væggen, som askebægre, på lampeskærme! For firmaet Sylvest Jensen er det et tab, at stifteren Viggo Sylvest Jensen omkommer ved en bilulykke i Sverige december 1959.

Den systematiske gennemfotografering af landets enkelte egne ophører, og optagelserne bliver mere spredte. Bestillingsarbejdet ind tager en stadig større rolle, her er det især den nye industri, der danner kundegrundlaget, det er den, der sikrer firmaet Sylvest Jensens fortsættelse. Flere firmaer lukker i 


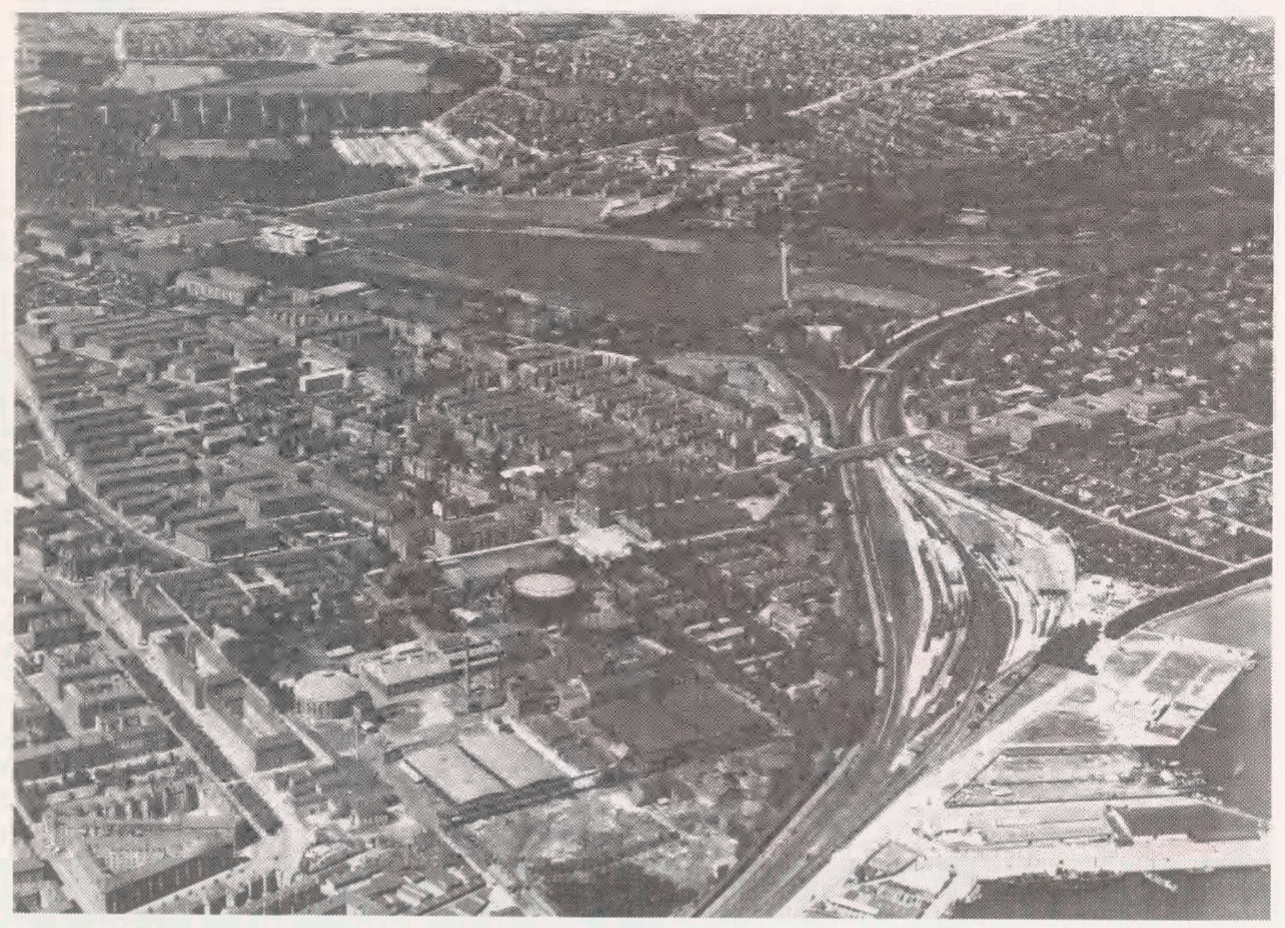

Østre Gasværk. Aero Express. 1939.

denne periode, vi nævner blot Odense og Ålborg Luftfoto, andre firmaer formår at klare sig.

I 1989 erhverver Det kongelige Bibliotek Sylvest Jensens store og værdifulde arkiv. 